\title{
利用子房滴注法获得无载体骨架序列和选择标记的转 基因玉米
}

杨爱馥，苏乔，安利佳

大连理工大学环境与生命学院, 大连 116024

摘要: 转基因植物中的载体骨架序列和选择标记基因是引起生物安全性争论的根本原因, 最直接、最有效的解 决方法是在转化过程中不使用载体骨架序列和选择标记基因。本研究建立并优化了玉米子房滴注转化法, 其操 作要点是将 DNA 转化溶液直接滴加在完全去除花柱的子房上。利用子房滴注法将无载体骨架序列和选择标记 的线性 GFP 基因表达框转化玉米。PCR 结果表明：适合子房滴注法转化的玉米品种为 9818 , 最佳转化时间为 授粉后 18 20 h, 在此条件下得到最高的 PCR 阳性率, 为 3.01\%; Southern blotting 结果表明外源基因的整合方式 简单(1 2 条杂交带); RT-PCR 结果表明转基因植株中 GFP 基因能够在 RNA 水平上正常表达; 在转基因植株的 根和幼肧中观察到 GFP 表达。

关键词: GFP；无载体骨架；无选择标记；子房滴注法；转基因玉米

\section{Generation of vector backbone-free and selectable marker-free transgenic maize (Zea mays L.) via ovary-drip method}

\author{
YANG Ai-Fu, SU Qiao, AN Li-Jia \\ Department of Bioscience and Biotechnology, Dalian University of Technology, Dalian 116024, China
}

\begin{abstract}
The presence of vector backbone sequences and selectable marker genes in transgenic plants has been the key concern for biosafety. A direct solution is to totally avoid the use of vector backbone sequences and selectable marker genes from the beginning of transgenic plant generation. In this study, the ovary-drip method was established and optimized. The key features of this method focused on the complete removal of the whole styles, and the subsequent application of a DNA solution directly to the ovaries. A vector backbone-free and selectable marker-free linear GFP cassette (Ubi-GFP -nos) was transformed into maize via the ovary-drip method. PCR analysis showed that suitable maize variety was 9818 and optimal transformation time was 18-20 h after pollination, which produced the highest PCR positive frequency (3.01\%). Southern blotting analysis showed that the transgenic plants had simple integration patterns (1-2 bands). GFP transcription was detected by RT-PCR analysis. Green fluorescence was observed in roots and immature embryos of transgenic plants by a fluorescence microscopy.
\end{abstract}

Keywords: GFP; vector backbone-free; selectable marker-free; ovary-drip method; transgenic maize

收稿日期: 2008-08-25; 修回日期: 2008-10-06 基金项目: 辽宁省科技攻关项目(编号：2006208001)资助 作者简介: 杨爱馥(1978-), 女, 博士研究生, 研究方向 : 植物基因工程。E-mail: yangaifu@yahoo.com.cn 通讯作者: 苏乔(1971-), 女, 副教授, 博士, 研究方向：分子生物学和作物遗传育种。Tel: 0411-84706356; E-mail: dsuqiao@yahoo.cn 
随着转基因植物的产业化种植和人们对生物安 全性的关注, 载体骨架序列(被称为“垃圾 DNA”) 和选择标记基因的安全性已成为农业转基因生物安 全性评价的重要对象之一。但目前普遍采用的转化 方法, 无论是农杆菌介导法还是基因枪法, 由于质 粒载体骨架序列常常随着目的基因整合到植物基因 组中 ${ }^{[1]}$, 产生重组热点或导致异常重组 ${ }^{[2]}$, 重组产生 的基因多拷贝常常影响基因表达甚至导致转基因沉 默 ${ }^{[3]}$ 。尽管近几年已有报道将无载体骨架序列的线 性基因表达框利用基因枪法成功导入水稻 ${ }^{[4 \sim 6]}$ 、小 麦 ${ }^{[7,8]}$ 、葡萄 ${ }^{[9]}$ 和马铃薯 ${ }^{[10]}$ 基因组, 但仍然依靠选择 标记基因篮选转化体。此外, 人们在建立无选择标 记基因的转化体系方面已取得了一定进展, 如通过 位点特异性重组 ${ }^{[11,12]}$ 、转座子介导的再定位 ${ }^{[13,14]}$ 、 共转化 ${ }^{[15]}$ 等方法去除选择标记基因。然而, 解决转 基因植物中载体骨架序列和选择标记基因问题最直 接、最有效的方法是在转化过程中不使用载体骨架 序列和选择标记基因。

玉米是重要的粮食兼饲料作物, 玉米产业在中 国国民经济中占有非常重要的地位。本研究以玉米 为试材, 建立并优化了子房滴注转化法。该方法操 作简单、无需植物组织培养过程, 直接将无载体骨 架和选择标记的线性基因表达框转化植物, 获得具 有生物安全性的转基因植株。本研究为培育具有生 物安全性的转基因作物开辟了新途径。

\section{1 材料和方法}

\section{1 材料}

供试的玉米自交系 9818、Shen137 和 H19 由辽 宁省农业科学院提供。质粒 pUC118-GFP 由本实验 室构建保存。

\section{2 方法}

\subsection{1 线性 GFP 表达框的制备}

以质粒 PUC118-GFP 为模板, 通过 PCR 扩增获 得线性 GFP 表达框(图 1)。上游引物为 ubi-PT1: 5' TGGCAGGATATATTGTGGTGTAAACCTGCAGTGC AGCGTGACCCGGTCGTG-3', 下游引物为 PT2: 5' GTTTACCCGCCAATATATCTGTCACCGATCTAGTAC ATAGATGACACCGC-3' (T-DNA 左右边界序列标 记为斜体)。反应条件为 $94^{\circ} \mathrm{C}$ 预变性 $5 \mathrm{~min} ; 94^{\circ} \mathrm{C}$ 变性 $30 \mathrm{~s}, 55^{\circ} \mathrm{C}$ 复性 $40 \mathrm{~s}, 72^{\circ} \mathrm{C}$ 延伸 $3 \mathrm{~min}, 35$ 个循环; $72^{\circ} \mathrm{C}$ $10 \mathrm{~min} ; 4^{\circ} \mathrm{C}$ 终止反应。扩增产物经氯仿/异戊醇抽提, 乙醇沉淀, $75 \%$ 乙醇洗涤吹干后, 溶于 $0.1 \times$ SSC 转 化溶液; 经 $1 \%$ 琼脂糖凝胶电泳检测确定浓度 (200 ng/ $\mu \mathrm{L}), 4^{\circ} \mathrm{C}$ 保存备用。

\subsection{2 子房滴注法转化玉米}

转化试验在 2005 年和 2006 年的 7 月和 8 月进 行。待玉米植株生长至开花期, 按常规方法进行雌、 雄花套袋隔离, 雄花套袋隔离 $24 \mathrm{~h}$ 后对雌花进行授 粉, 授粉后在所设时间段内, 在雌穗中部将苍叶切 开一个“窗口”, 将露出的玉米子房上的花柱全部切 除, 用消毒过的大头针标记位置, 然后用微量进样 器吸取 $5 \mu \mathrm{L}$ DNA 转化溶液滴加在去掉花柱的子房 伤口处, 对照植株只转化缓冲液, 将“窗口”合上, 然 后在整个雌穗外面套袋, 待果穗成熟收获。

\subsubsection{PCR 检测}

转化后发育成熟的种子在培养箱中萌发, 待子 叶发育成 $1 \mathrm{~cm}$ 左右时移栽至培养钵中, 温室内常规 培养, 待幼苗长出第二片新叶时, 用 CTAB 法提取 待检测材料的叶片基因组 DNA, 以此为模板进行 PCR 检测。检测用上游引物为 $5^{\prime}$-CAAGGACGACG

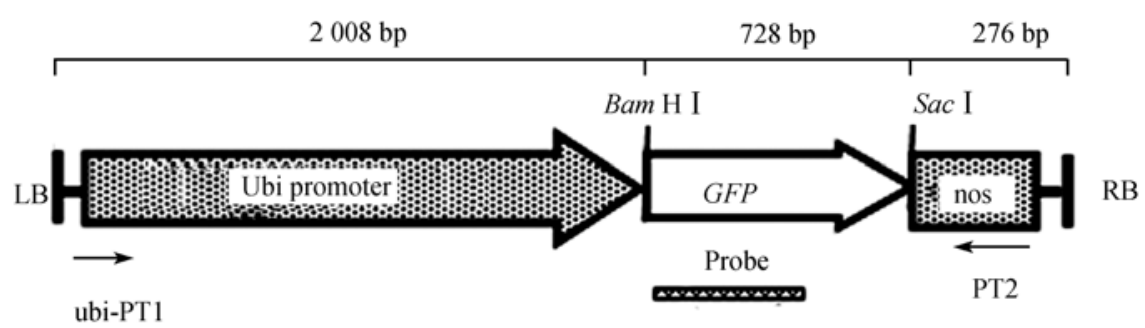

图 1 无载体骨架序列的线性 GFP 表达框 
GGAACT-3 位于 GFP 基因上, 下游引物为 $5^{\prime}$-AAC CCATCTCATAAATAACG-3’ 位于 nos 终止子上, 扩 增片段长度为 $578 \mathrm{bp}$ 。反应条件为 $94^{\circ} \mathrm{C}$ 预变性 $5 \mathrm{~min}$; $94^{\circ} \mathrm{C}$ 变性 $30 \mathrm{~s}, 58^{\circ} \mathrm{C}$ 复性 $40 \mathrm{~s}, 72^{\circ} \mathrm{C}$ 延伸 $1 \mathrm{~min}, 30$ 个 循环; $72^{\circ} \mathrm{C} 10 \mathrm{~min} ; 4^{\circ} \mathrm{C}$ 终止反应。

\subsubsection{Southern blotting 分析}

$40 \mu \mathrm{g}$ 基因组 DNA 经 $E c o$ R I 酶切过夜(EcoR I 在表达框上无酶切位点), 毛细管法 ${ }^{[16]}$ 转至尼龙膜用 于杂交分析。以质粒 pUC118-GFP 为模板 PCR 扩增 的 GFP 基因上 569 bp 片段为探针。上游引物为 $5^{\prime}$ CAAGGACGACGGGAACT-3'; 下游引物为 $5^{\prime}$-GG ACCATGTGATCGCGCTTCTCGTT-3”。探针标记、 杂交与检测按照 DIG High Prime Labeling and Detection Starter Kit (Roche) 说明进行。

\subsubsection{RT-PCR 分析}

采用 TRIZOL RNA 提取试剂(Invitrogen)提取转 基因植株叶片 RNA。按照 RNA PCR Kit (AMV) Ver.3.0(TakaRa)试剂盒说明将 RNA 反转录成 cDNA。 PCR 反应上游引物为 $5^{\prime}$-CAAGGACGACGGGAAC T-3', 下游引物为 $5^{\prime}$-TTGTTTGTCTGCCGTGAT-3', 扩增片段长度为 $379 \mathrm{bp}$ 。反应条件为 $94^{\circ} \mathrm{C}$ 预变性 $5 \mathrm{~min} ; 94^{\circ} \mathrm{C}$ 变性 $30 \mathrm{~s}, 56^{\circ} \mathrm{C}$ 复性 $40 \mathrm{~s}, 72^{\circ} \mathrm{C}$ 延伸 $1 \mathrm{~min}$, 30 个循环; $72^{\circ} \mathrm{C} 10 \mathrm{~min}, 4^{\circ} \mathrm{C}$ 终止反应。

\subsubsection{GFP 表达检测}

取转基因材料的根和授粉后 $10 \mathrm{~d}$ 的幼胚, 在苂 光显微镜(Olympus IX71, Japan)下观察 GFP 表达。激 发光波长为 $450 \sim 490 \mathrm{~nm}$; 发射光波长为 $515 \sim 560 \mathrm{~nm}$ 。

\section{2 结果与分析}

2.1 玉米品种和转化时间对子房滴注法转化率的影响

为了保证转化外源 DNA 溶液的子房能够发育 成果实, 即去除花柱时花粉管已进入子房, 我们先 进行了苯胺兰染色观察花粉管的预实验。结果表明 授粉后 $16 \mathrm{~h}$, 花粉管进入子房, 沿着花粉管通道延 伸, 通过珠孔, 进入胚囊。因此将子房滴注法转化操 作开始时间确定为授粉后 $16 \mathrm{~h}$ 。将授粉后时间划分 为 $16 \sim 18 \mathrm{~h} 、 18 \sim 20 \mathrm{~h} 、 20 \sim 22 \mathrm{~h}$ 和 22 24 h, 以 9818 、 Shen137 和 $\mathrm{H} 19$ 为试材, 对玉米品种和转化时间对 子房滴注法转化率的影响进行了探讨。从表 1 可以 看出, 玉米品种 9818 和 Shen137 检测出 PCR 阳性株 (图 2), 而 H19 未检测到 PCR 阳性株。玉米品种 9818 在授粉后 16 18 h 和 18 20 h, PCR 阳性率分别为 $0.50 \%$ 和 3.01\%; 玉米品种 Shen 137 在授粉后 18 20 h 和 20 22 h, PCR 阳性率分别为 $0.74 \%$ 和 $0.89 \%$ 。因 此确定 9818 为适合子房滴注法转化的玉米品种, 最 佳转化时间为授粉后 18 20 h, 此时 9818 得到最高 的 PCR 阳性率，为 $3.01 \%$ 。

\section{2 转基因植株的 Southern blotting 分析}

Southern blotting 用来检测限制性核酸内切酶切 割的植物 DNA 片段中是否存在与探针同源的序列, 并可分析外源基因在植物染色体上的整合情况。随机 选取部分 PCR 阳性株进行 Southern blotting 检测。如 图 3 所示, Southern blotting 结果显示 1 2 条杂交带, 表 明外源基因在植物基因组中的整合位点位为 $1 \sim 2$ 个, 整 合方式简单。未转化样品无杂交信号。Southern blotting 进一步证明了外源 GFP 基因整合到植物基因组。

表 1 玉米品种和转化时间对子房滴注法转化率的影响

\begin{tabular}{|c|c|c|c|c|}
\hline 玉米品种 & 转化时间(h) & 检测植株数 & PCR 阳性株数 & PCR 阳性率(\%) \\
\hline \multirow[t]{4}{*}{9818} & 16 18 & 398 & 2 & 0.50 \\
\hline & $18 \sim 20$ & 564 & 17 & 3.01 \\
\hline & $20 \sim 22$ & 420 & 0 & 0 \\
\hline & $22 \sim 24$ & 141 & 0 & 0 \\
\hline \multirow[t]{4}{*}{ Shen 137} & $16 \sim 18$ & 98 & 0 & 0 \\
\hline & $18 \sim 20$ & 135 & 1 & 0.74 \\
\hline & $20 \sim 22$ & 112 & 1 & 0.89 \\
\hline & $22 \sim 24$ & 87 & 0 & 0 \\
\hline \multirow[t]{4}{*}{ H19 } & $16 \sim 18$ & 84 & 0 & 0 \\
\hline & $18 \sim 20$ & 135 & 0 & 0 \\
\hline & $20 \sim 22$ & 126 & 0 & 0 \\
\hline & $22 \sim 24$ & 95 & 0 & 0 \\
\hline
\end{tabular}




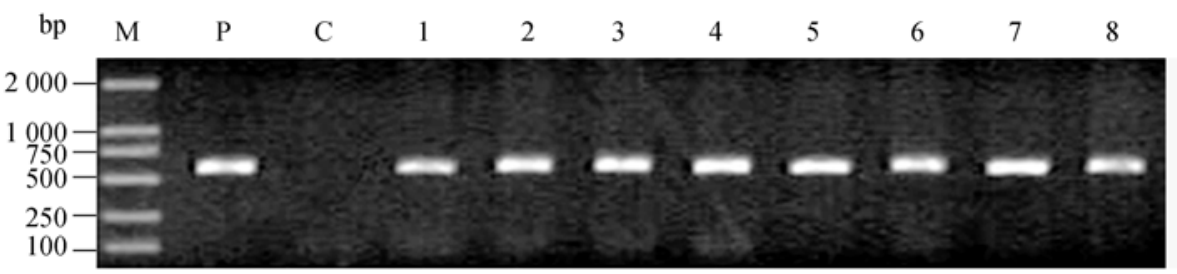

图 2 PCR 检测结果

M: DL2000 marker (TaKaRa); P：质粒 DNA 作为阳性对照; C: 未转化材料作为阴性对照; 1 8: 转化材料。

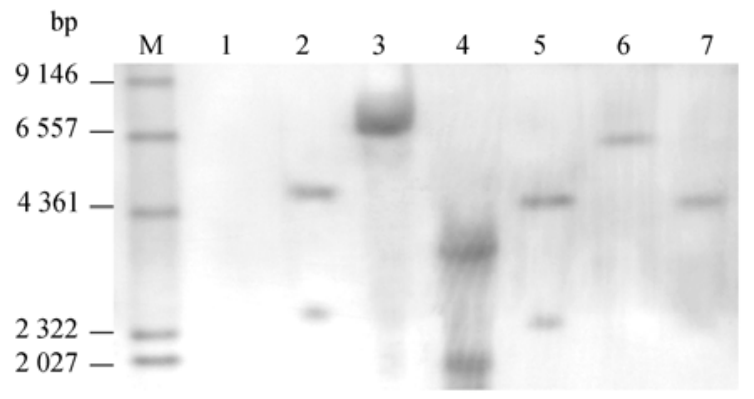

图 3 Southern blotting 结果

M: DNA 分子量标准 II (Roche); 1：未转化玉米材料; 2 7：转基因株 系 L1 L6。

\section{3 转基因植株的 RT-PCR 分析}

对 6 株 Southern 阳性株和 4 株 PCR 阳性株进行 RT-PCR 检测, 分析外源 GFP 基因在 RNA 水平上的 表达情况。从植株叶片中提取总 RNA, 用随机引物 反转录成 cDNA, 经 PCR 扩增, 所有样品均扩增出 大小为 $379 \mathrm{bp}$ 目的条带(图 4), 表明转基因植株中外 源 GFP 基因能够在 RNA 水平上正常表达。

\subsection{GFP 苂光观察}

取转基因植株的根和授粉后 $10 \mathrm{~d}$ 的幼胚, 在苂 光显微镜下观察 GFP 表达。转基因植株的根和幼胚
在激发光波长为 $450 \sim 490 \mathrm{~nm}$ 的蓝光下均发出特异 绿色苂光, 而未转化材料在同一视野、同一曝光强 度呈现微弱的自发苂光(图 5)。结果表明外源 GFP 基因在转基因植株中能够正常表达。共观察了表 1 所示的 21 株 PCR 阳性植株的根, 均观察到 GFP 的 表达。观察了 3 个 Southern 阳性株系的幼胚, GFP 阳性幼胚的百分比分别为 $53.13 \% 、 70.73 \%$ 和 $32.14 \%$ (表 2)。幼胚中观察到 GFP 表达也表明外源 GFP 基 因能够在后代中遗传。

3 讨 论

\section{1 影响玉米子房滴注法转化率的因素探讨}

玉米品种对子房滴注法转化率的影响可能是由 不同品种玉米子房外部形态所决定的。玉米品种 H19 的转化率为 0 , Shen 137 的转化率也较低, 是因 为这两个品种的子房表面非常光滑, 转化溶液很难 在子房伤口处停留, 故降低了外源 DNA 进入子房的 机会, 从而降低了转化率, 甚至未能成功转化。而玉 米品种 9818 的子房表面有一层薄膜包裹, 将花柱去 除后, 子房切口与薄膜形成凹面, 转化溶液可长时 间停留在子房切口处, 增加了外源 DNA 进入子房的 机会, 因而具有较高的转化率。

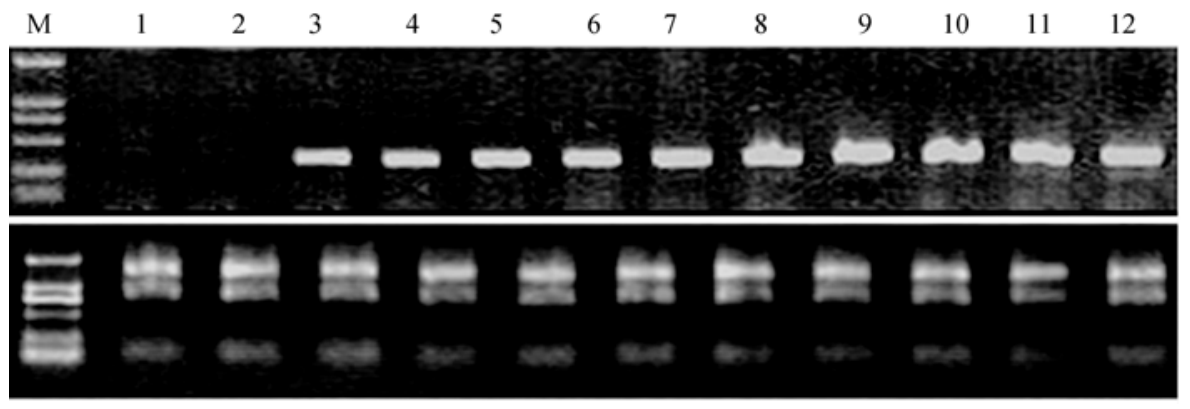

图 4 RT-PCR 结果

上排 M: DL2000 marker; 1: 未转化玉米材料 cDNA(不加反转录酶); 2: 未转化玉米材料 cDNA(加反转录酶); 3 12: 转基因株系。下排为 RNA。 
根据植物胚胎学的研究结果, 外源 DNA 转化的 时期应限定在精卵融合至合子分裂前这一段时期, 此时合子合点端的细胞壁尚未封闭, 合子的合点端 是以质膜与中央细胞的质膜相靠。此时的合子可以 看成原生质体的状态，外源 DNA 可能由合子的质膜

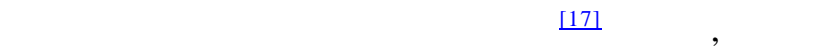
转化时间的确定是子房滴注法成功的关键因素之
一。本研究通过 PCR 检测确定授粉后 18 20 h 为玉 米子房滴注法最佳转化时间。

\section{2 子房滴注法转化线性 DNA 片段整合方式分析}

Southern blotting 结果表明线性 DNA 片段通过 子房滴注法转化玉米，外源基因以简单的方式(1 2 个整合位点)整合到植物基因组上。2000 年, $\mathrm{Fu}$ 等 ${ }^{[4]}$
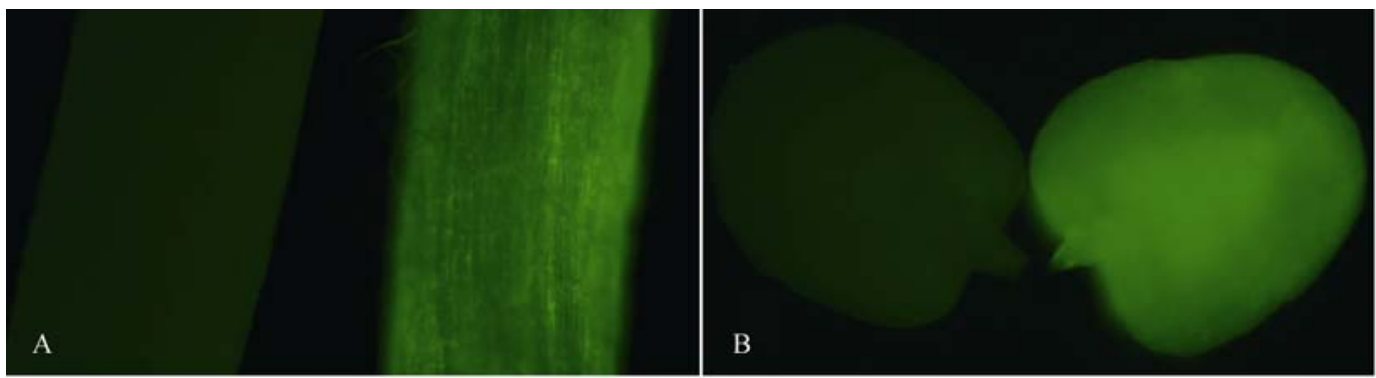

图 5 GFP 在转基因植株中的表达

A: GFP 在转基因植株根中的表达; B: GFP 在转基因植株幼胚中的表达。

表 2 转基因株系中 GFP 在幼胚中的表达情况

\begin{tabular}{ccccc}
\hline 株系 & 观察幼胚数 & GFP 阳性幼胚数 & GFP 阴性幼胚数 & GFP 阳性幼胚 $(\%)$ \\
\hline L1 & 32 & 17 & 15 & 53.13 \\
L2 & 41 & 29 & 12 & 70.73 \\
L6 & 28 & 9 & 17 & 32.14 \\
\hline
\end{tabular}

将无载体骨架序列的线性 DNA 片段通过基因枪法 转化水稻，线性 DNA 片段是以低拷贝数、简单的整 合方式(1 2 个 Southern blotting 杂交带)整合于水稻 基因组上, 而且外源基因一直稳定遗传到第四代, 没有出现基因沉默现象。近几年, 线性 DNA 片段通 过基因枪法转化水稻、小麦、葡萄、马铃薯等同样 也获得了以低拷贝方式整合的转基因植株 ${ }^{[5 \sim 10]}$ 。这 种简单的整合方式更有利于外源基因的高水平表 达 ${ }^{[5,6]}$ 和稳定遗传 ${ }^{[4,7]}$ 。

\section{3 子房滴注法的优越性}

为了从根本上解决转基因植物可能引起的食物 安全性和环境安全性问题, 建立无载体骨架序列和 选择标记转化体系的研究已成为当前植物基因工程 领域的研究热点。子房滴注法在解决安全性问题的 研究中具有其他转基因方法不可比拟的优越性, 表 现在(1)可以实现无载体骨架序列和选择标记的线性 基因表达框转化植物, 直接获得具有生物安全性的 转基因植株; (2)该方法不依赖于组织培养和植株再 生过程, 可直接获得转基因种子, 避免了体细胞变
异对转基因植株表型的影响，一般不会形成嵌合体; (3)操作简便, 不需要昂贵的仪器设备, 易于常规育 种工作者掌握; (4)通过规范操作要点和确定最佳转 化时间，使子房滴注法具有较好的重复性。该方法 理论上适用于所有行有性生殖的植物, 为其他显花 植物无载体骨架序列、无选择标记基因转化体系的 建立奠定基础。

\section{参考文献(References):}

[1] Kononov ME, Bassuner B, Gelvin SB. Integration of T-DNA binary vector "backbone" sequence into the tobacco genome: Evidence for multiple complex patterns of integration. Plant J, 1997, 11(5): 945-957.[DOI]

[2] Muller AE, Kamisugi Y, Gruneberg R, Niedenhof I, Horold RJ, Meyer P. Palindromic sequences and ACT-rich DNA elements promote illegitimate recombination in Nicotiana tabacum. J Mol Biol, 1999, 291(1): 29-46.[DOI]

[3] Matzke MA, Matzke AJM, Eggleston WB. Paramutation and transgene silencing: A common response to invasive DNA? Trends Plant Sci, 1996, 1(11): 382-388.

[4] Fu XD, Duc LT, Fontana S, Bong BB, Tinjuangjun P, Sud- 
hakar D, Twyman RM, Christou P, Kohli A. Linear transgene constructs lacking vector backbone sequences generate low-copy-number transgenic plants with simple integration patterns. Transgenic Res, 2000, 9(4): 11-19.[DOI]

[5] Loc NT, Tinjuangjun P, Gatehouse AMR, Christou P, Gatehouse JA. Linear transgene constructs lacking vector backbone sequences generate transgenic rice plants which accumulate higher levels of proteins conferring insect resistance. Mol Breeding, 2002, 9(4): 231-244.[DOI]

[6] Agrawal PK, Kohli A, Twyman RM, Christou P. Transformation of plants with multiple cassettes generates simple transgene integration patterns and high expression levels. Mol Breeding, 2005, 16(3): 247-260.[DOI]

[7] Yao Q, Cong L, Chang JL, Li KX, Yang, GX, He GY. Low copy number gene transfer and stable expression in a commercial wheat cultivar via particle bombardment. $J$ Exp Bot, 2006, 57(14): 3737-3746.[DOI]

[8] Yao Q, Cong L, He GY, Chang JL, Li HX, Yang GX. Optimization of wheat co-transformation procedure with gene cassettes resulted in an improvement in transformation frequency. Mol Biol Rep, 2007, 34(1): 61-67.[DOI]

[9] Vidal JR, Kikkert JR, Donzellii BD, Walllace PG, Reisch BI. Biolistic transformation of grapevine using minimal gene cassette technology. Plant Cell Rep, 2006, 25(8): 807-814.[DOI]

[10] Romano A, Raemakers K, Bernardi J, Visser R, Mooibroek H.
Transgene organization in potato after particle bombardment-mediated (co-)transformation using plasmids and gene cassettes. Transgenic Res, 2003, 12(4): 461-473.[DOI]

[11] Sugita K, Kasahara T, Matsunaga E, Ebinuma H. A transformation vector for the production of marker-free transgenic plants containing a single copy transgene at high frequency. Plant J, 2000, 22(5): 461-469.[DOI]

[12] Hare PD, Chua NH. Excision of selectable marker genes from transgenic plants. Nat Biotechnol, 2002, 20(6): 575-580.

[13] Goldsbrough AP, Lastrella CN, Yoder J. Transposition mediated re-positioning and subsequent elimination of marker genes from transgenic tomato. Nat Biotechnol, 1993, 11(1): 1286-1292.

[14] Cotsaftis O, Sallaud C, Breitler JC. Transposon-mediated generation of marker free rice plants containing a $B t$ gene conferring insect resistance. Mol Breeding, 2002, 10(3): 165-180.[DOI]

[15] Breitler JC, Meynard D, Van BJ, Royer M, Bonnot F, Cambillau L, Guiderdoni E. A novel two T-DNA binary vector allows efficient generation of marker-free transgenic plants in three elite cultivars of rice (Oryza sativa L.). Transgenic Res, 2004, 13(3): 271-287.[DOI]

[16] 王关林, 方宏筠. 植物基因工程(第二版). 北京: 科学 出版社, 2002.

[17] 王艳杰, 申家恒. 花粉管通道法转基因技术的细胞胚胎 学机理探讨. 西北植物学报, 2006, 26(3): 628-634.

\section{•综合信息・}

\section{《遗传学报》获得 2007 年中国百种杰出学术期刊证书}

2008 年 12 月 9 日, 中国科学技术信息研究所主办的中国科技论文统计结果发布会在北京举行。会上发布了 2007 年中国百种杰出学术期刊、2008 年版中国科技期刊引证报告(核心版)等最新统计结果。《遗传学报》获得 2007 年中国 百种杰出学术期刊证书。同时，《遗传学报》和《遗传》还获得中国精品科技期刊证书。

这次获得 2007 年中国百种杰出学术期刊称号的期刊是(按汉语拼音顺序排列):

爆炸与冲击、北京大学学报自然科学版、草业学报、地理学报、地球物理学报、地学前缘、第三军医大学学报、 第四军医大学学报、电工技术学报、电子学报、东南大学学报自然科学版、分析化学、高等学校化学学报、管理科学 学报、光学学报、硅酸盐学报、海洋与湖沼、航空学报、核技术、化工学报、化学学报、环境科学、机械工程学报、 计算机学报、计算机研究与发展、交通运输工程学报、金属学报、精细化工、科学通报、矿物学报、力学进展、力学 学报、林业科学研究、摩擦学学报、南京农业大学学报、气象学报、清华大学学报自然科学版、软件学报、生态学报、 生物多样性、石油勘探与开发、石油学报、食品科学、世界胃肠病学杂志(英文版)、数学学报、水利学报、通信学报、 土木工程学报、土壤学报、无机材料学报、物理学报、西安交通大学学报、系统工程理论与实践、岩土工程学报、遥 感学报、药学学报、仪器仪表学报、遗传学报、植物生理与分子生物学学报、植物营养与肥料学报、中草药、中国病 理生理杂志、中国电机工程学报、中国感染与化疗杂志、中国公路学报、中国机械工程、中国科学 D、中国科学 $\mathrm{E} 、 中$ 国农业大学学报、中国农业科学、中国水产科学、中国危重病急救医学、中国物理 B、中国稀土学报、中国烟草学报、 中国药学杂志、中国有色金属学报、中国中西医结合杂志、中华病理学杂志、中华儿科杂志、中华放射学杂志、中华 骨科杂志、中华护理杂志、中华检验医学杂志、中华结核和呼吸杂志、中华口腔医学杂志、中华流行病学杂志、中华 麻醉学杂志、中华神经科杂志、中华外科杂志、中华心血管病杂志、中华眼科杂志、中华医学杂志、中华医学杂志英 文版、中华肿瘤杂志、中山大学学报自然科学版、自动化学报、自然科学进展、自然资源学报、作物学报。 